\title{
GEOLOGY OF THE POINT REYES NATIONAL SEASHORE AND VICINITY, MARIN COUNTY, CALIFORNIA: A DIGITAL DATABASE
}

By

\author{
Joseph C. Clark and Earl E. Brabb
}

\section{GENERAL GEOLOGY}

The Point Reyes Peninsula is a roughly triangular projection of the Marin County coast with an apex at Point Reyes and a base along Tomales Bay and the rift valley of the San Andreas fault zone. This fault zone forms the active tectonic boundary between the Pacific and North American lithospheric plates and here separates Upper Cretaceous granitic and older metamorphic rocks of the Salinian block to the west from Upper Jurassic to Lower Cretaceous graywacke sandstone and melange of the Franciscan complex to the east.

Resting nonconformably upon the crystalline basement of the Point Reyes Peninsula is a composite section of as much as 4,370 m (14,340 ft) of moderately deformed Tertiary marine sedimentary rocks that comprise three sequences, separated by unconformities. The oldest sequence consists of as much as $210 \mathrm{~m}(700 \mathrm{ft})$ of the Point Reyes Conglomerate of Galloway (1977) of early Eocene age that rests depositionally upon the porphyritic granodiorite of Point Reyes.

A middle and upper Miocene sedimentary sequence is as much as 1,610 m (5,300 ft.) thick and consists of a basal sandstone unit, the Laird Sandstone, and an overlying porcelanite unit, the Monterey Formation. This Neogene sequence crops out on the southwest slope of Inverness Ridge, where it rests nonconformably upon the granodiorite and granite of Inverness Ridge.

Resting unconformably on all older rocks of the Point Reyes Peninsula are the widely transgressive beds of the upper Miocene and Pliocene sedimentary sequence. This youngest sequence is as much as 2,550 m (8,500 ft.) thick and consists of a basal glauconitic sandstone unit, the Santa Margarita Sandstone, a siliceous mudstone unit, the Santa Cruz Mudstone, and an upper siltstone, mudstone, and sandstone unit, the Purisima Formation. Clark and others (1984) applied these formational names from the Santa Cruz Mountains to the correlative units at Point Reyes because of their very similar stratigraphic relationships, lithologies, and fossil faunas and floras.

A complete superpositional section is nowhere exposed on the Point Reyes Peninsula, and good rock exposures are generally restricted to the sea cliffs. Three deep exploration wells (wells 4, 5, and 6, sheet 1) penetrated thick sections of the upper Miocene and Pliocene sequence and of the middle and upper Miocene sequence (see Oil Test Wells, sheet 1). Additionally, the Chevron

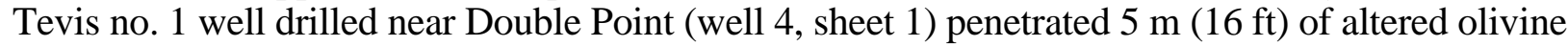
pyroxene basalt beneath the middle and upper Miocene sequence and above as much as $502 \mathrm{~m}$ (1,646 ft) of dark shale of early Eocene age (Kris McDougall, written commun., 1997).

The close similarity of the Upper Cretaceous porphyritic granodiorites and of the lower Eocene and middle and upper Miocene sequences of the Point Reyes and Monterey Peninsulas suggests as much as $150 \mathrm{~km}$ (94 mi) of total right slip displacement on the San Gregorio fault in the last $11 \mathrm{Ma}$. Similarities of the glauconitic Santa Margarita and of the thick Santa Cruz Mudstone sections of the upper Miocene and Pliocene sequences of the Point Reyes Peninsula and of the central Santa Cruz Mountains indicate that 70 to $90 \mathrm{~km}$ (44 to $56 \mathrm{mi}$ ) of this offset occurred in the last 6 to $8 \mathrm{Ma}$. 


\section{DESCRIPTION OF ROCK UNITS}

\section{ROCK UNITS WEST OF SAN ANDREAS FAULT ZONE}

Metamorphic rocks -- Mica schist, impure quartzite, calc-hornfels, and graphitic marble locally containing scheelite occur as inclusions and small roof pendants in the granodiorite and granite of Inverness Ridge. Garnet- and sillimanite-bearing quartzofeldspathic gneiss and granofels form a septum at McClures Beach between the tonalite of Tomales Point and the granodiorite and granite of Inverness Ridge (Ross, 1977, 1978). Although Cretaceous granitic rocks intrude these metasedimentary rocks, their age is uncertain but is probably Mesozoic or Paleozoic.

Tonalite of Tomales Point -- Hornblende-biotite tonalite that contains dark diorite inclusions forms the basement of Tomales Point. This rock is lithologically similar to the tonalite that crops out at Bodega Head about $10 \mathrm{~km}$ to the north, and both are probably part of the same granitic mass (Ross, 1978). K-Ar dating of hornblende in the tonalite of Bodega Head yields an age of 94.3 Ma (Late Cretaceous) (Evernden and Kistler, 1970; recalculated using new constants in Dalrymple, 1979).

Granodiorite and granite of Inverness Ridge -- Granodiorite and granite are exposed along Inverness Ridge, where dikes and masses of aplite and alaskite are locally abundant.

Porphyritic granodiorite of Point Reyes -- Porphyritic granodiorite that crops out at Point Reyes contains K-feldspar phenocrysts that average 2 to $3 \mathrm{~cm}$ and are as long as $5 \mathrm{~cm}$; locally this rock is not porphyritic. The granodiorite has 2 to 12 percent biotite and hornblende, about 30 percent quartz, 25 to 35 percent K-feldspar, and the remainder plagioclase. Chemically, it is about 70 percent $\mathrm{SiO}_{2}, 15$ percent $\mathrm{Al}_{2} \mathrm{O}_{3}, 2.6$ percent $\mathrm{Fe} 0,2.8$ percent $\mathrm{Ca} 0,3.3$ percent $\mathrm{Na}_{2} 0$, and 3.4 percent $\mathrm{K}_{2} 0$ (from Ross in Clark and others, 1984; and Ross, 1984). K-Ar dating of biotite in this granodiorite gives an age of 82.0 Ma (Late Cretaceous) (Curtis and others, 1958; recalculated using new constants in Dalrymple, 1979), and fisson-track dating of sphene from this rock yields ages of $82.7 \pm 6.9$ and $86.8 \pm 7.4 \mathrm{Ma}$ (Late Cretaceous) (Naeser and Ross, 1976).

Point Reyes Conglomerate of Galloway (1977) -- Very thick, graded arkosic sandstone beds and very thick sandy conglomerate beds, locally channelled into the sandstone, rest nonconformably on the porphyritic granodiorite of Point Reyes. The conglomerate consist of 30 to 50 percent subangular porphyritic granodiorite clasts as much as 2 to $3 \mathrm{~m}$ long, 30 to 40 percent well-rounded purple and black porphyritic siliceous volcanic pebbles and cobbles, and 10 to 20 percent light-colored quartzite pebbles, with lesser red chert and black and green volcanic pebbles. As much as $210 \mathrm{~m}$ of section crops out near the Point Reyes lighthouse. These beds were probably laid down in a northwesterly-trending, upper mid-fan submarine channel complex (Clark and others, 1984). Arenaceous benthic foraminifers in one surface sample are typical of bathyal depths and indicated to Galloway (1977) a Paleocene age. McDougall (written commun., 1997) has reinterpreted this fauna and believes that the age is early Eocene, Penutian, coeval with planktic foraminiferal zones P6b to early P9, based on the joint occurence of Karreriella elongata $(=K$. mediaaguaensis), Pelosina complanata, Silicosigmolina californica, and Spiroplectammina directa $(=S$. perplexa $)$. McDougall also examined several cores from mudstones in the Chevron Tevis well (\#4 on geologic map) in the intervals from 5058 to 6097 feet where the foraminifers are better preserved, more diverse, and contain more index species than the Galloway sample. The Tevis samples are also early Eocene, Penutian, P6b, P8, and P6b to early P9. 
Laird Sandstone -- Very-thick-bedded, light-gray, medium-to-fine-grained, biotitic arkosic sandstone with scattered calcareous concretions locally includes a thick boulder granitic conglomerate at base. Rests nonconformably on the granodiorite and granite of Inverness Ridge and on the tonalite of Tomales Point. As much as $64 \mathrm{~m}$ thick at Kehoe Beach, this sandstone unit thins to the east to less than $12 \mathrm{~m}$ near Lairds Landing on Tomales Bay. Mollusks and echinoids from near the base of the Kehoe Beach section are diagnostic of shallow-marine depths and middle Miocene age (Clark and others, 1991).

Monterey Formation -- Thin-bedded and laminated, light-colored porcelanite with very thinly laminated shale interbeds and few thin to medium interbeds of biotitic arkosic sandstone is as thick as $450 \mathrm{~m}$ on the southwest slope of Inverness Ride. Interbedded light-gray porcelanite, brown brittle chert, and dark-yellowish-brown mudstone with scattered dolomite concretions that form the upper part of the Monterey are estimated to be from 450 $\mathrm{m}$ to $900 \mathrm{~m}$ thick (Clark and others, 1984). The Lockhart well on Bolinas Mesa (well no. 6 , sheet 1) penetrated as much as $1500 \mathrm{~m}$ of the Monterey. This formation yields benthic foraminfiers diagnostic of bathyal or greater depths and of Luisian and Mohnian (middle and late Miocene) age with most of the Monterey being Mohnian (Clark and others, 1984).

Santa Margarita Sandstone -- Massive, coarse - to fine-grained semifriable arkosic sandstone is commonly greenish where it contains 37 to 42 percent glauconite. In seacliff exposures near Double Point this sandstone is highly bioturbated and bituminous. At Santa Maria Beach a one-meter thick basal conglomerate contains abundant Monterey chert clasts, common greenish and black porphyritic siliceous volcanic clasts, and a few granitic pebbles. The Santa Margarita rests with angular unconformably on the Point Reyes Conglomerate of Galloway (1977) at Point Reyes and on the Monterey Formation east of Drakes Bay, where it varies from $5 \mathrm{~m}$ to as much as $60 \mathrm{~m}$ thick. The glauconitic sandstone has yielded a K-Ar date of 7.9 $\pm 0.3 \mathrm{Ma}$ (Geochron Labs., 1997). which is late Miocene. Stratigraphic relationships to the under- and overlying formations also indicate that the Santa Margarita is late Miocene age.

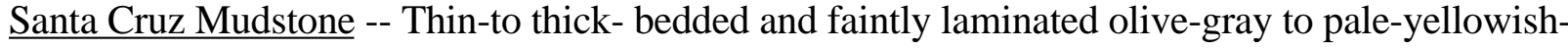
brown siliceous mudstone contains thin elongate carbonate concretions. Silica content varies from 66.4 percent near Bolinas to 79.0 percent higher in the section (Clark and others, 1984, table 2). In the seacliffs southeast of Double Point, contains a few thin bituminous sandstone interbeds, whereas farther southeast bituminous sandstone dikes are locally common in the lower part of the mudstone section. As much as $1040 \mathrm{~m}$ of mudstone are exposed between Bolinas and Duxbury Points. With additional subsurface section, this formation may be as thick as $2000 \mathrm{~m}$ in the Bolinas Mesa area but thins to the northwest, where it pinches out east of Drakes Bay. A diatom flora from near Bolinas Point is assigned to the Nitzchia reinholdii zone of late Miocene age (John A. Barron, written commun., 1975, 1990). Calcareous benthic foraminifers are diagnostic of the Bolivina obliqua zone of late Miocene age (Clark and others, 1984, table 3).

Purisima Formation -- Thick- to very-thick bedded, light-olive-gray siltstone is locally diatomaceous and upon weathering becomes nodular and yellowish gray. Spheroidal carbonate concretions, elongate as much as $2 \mathrm{~m}$, form prominent discontinuous interbeds and locally contain cetacean bones. Several thick interbeds of light-olive-gray, well-sorted, fine- to medium-grained lithic arkose appear "bluish" where fresh, are semifriable and commonly bioturbated. In the broad synclinal section at Drakes Bay, the Purisima is as much as $490 \mathrm{~m}$ thick. A diatom flora from the seacliff section at Drakes Beach is assigned to subzone $\mathrm{b}$ of the Nitzchia reinholdii zone of latest Miocene age (Zone X in Clark and others, 1984). The pinniped fauna is diagnostic of latest Miocene or Pliocene age (Repenning and Tedford, 1977). As much as $40 \mathrm{~m}$ of the Purisima at Drakes Bay is latest 
Miocene, but the upper part that is not as well dated is believed to range into the Pliocene (Clark and others, 1984).

\section{ROCK UNITS WITHIN SAN ANDREAS FAULT ZONE}

Merced Formation -- Weakly consolidated, thick-bedded, bluish-gray, sandy siltstone with crossbedded, fine-grained silty sandstone and interbedded pebble conglomerate in upper part is exposed in cliff section at Bolinas. Calcareous concretions commonly contain fossil shells and carbonized wood, whereas the siltstones locally contain abundant calcareous foraminifers. The cliff section is about $70 \mathrm{~m}$ thick; water wells about $2 \mathrm{~km}$ to the north have penetrated 85 to $91 \mathrm{~m}$ of Merced without reaching its base (Wagner, 1977). Mollusks and benthic foraminifers indicate shallow-marine nearshore and backshore conditions (Galloway, 1977). Correlative with the type Merced about $30 \mathrm{~km}$ to the south that ranges in age from late Pliocene (3.2 Ma) to Pleistocene (200 ka) (K.R. Lajoie, written commun., 1996).

Millerton Formation -- Poorly consolidated and deeply weathered clay, silt, sand, and gravel contain abundant fossil fauna and flora. Restricted to terraces along eastern margin of Tomales Bay, where formation is as much as $30 \mathrm{~m}$ thick. Deposited in alluvial to estuarine environments during Pleistocene time. Dating by thermoluminescence methods yields an age of $134 \pm 12 \mathrm{ka}$ (middle Pleistocene) (G.W. Berger, pers. commun., 1994, in Grove and others, 1995).

Olema Creek Formation -- Granitic sand and gravel is interbedded with organic-rich mud and peat. Exposed south of Tomales Bay, where formation is as much as $170 \mathrm{~m}$ thick (Grove and others, 1995). Interbedded estuarine and alluvial sediments were deposited on a coastal plain near a bay head during Pleistocene time (Grove and others, 1995).

Thermoluminescence dating yields an age of $132 \pm 28 \mathrm{ka}$ (middle Pleistocene) (G.W. Berger in Grove and others, 1995), suggesting that this formation was deposited at about the same time as the Millerton Formation.

\section{ROCK UNITS EAST OF SAN ANDREAS FAULT ZONE}

Franciscan complex -- Sheared shale and sandstone contains hard tectonic inclusions predominantly of greenstone, chert, and graywacke and variably resistant masses of graywacke, greenstone, and serpentinite (Blake and others, 1974). This sheared rock or melange that crops out east of Tomales Bay is assigned to the Central tectonostratigraphic terrane of Blake and others (1984) of Late Jurassic and Early Cretaceous age (Wahrhaftig and Wakabayashi, in Wahrhaftig and Sloan, 1989). Graywacke and interbedded shale with minor conglomerate of the San Bruno Mountain terrane form Bolinas Ridge southeast of Point Reyes Station. East of Point Reyes Station this sandstone and shale locally has been hydrothermally altered (Blake and others, 1974). Limestone is present at Olema, indicating that the Franciscan in this area belongs to the Permanente terrane.

Wilson Grove Formation -- Light-gray, fine-to very-fine-grained sandstone with thin pebble conglomerate lenses and coarse- to very-coarse-grained sandstone that is locally pebbly and forms resistant outcrops are mostly marine. Correlation of an interbedded tuff $15 \mathrm{~km}$ northeast of map area indicates an age of $6.26 \pm 0.38 \mathrm{Ma}$ (late Miocene) (A. M. SarnaWojcicki, written commun., 1997). 


\section{SURFICIAL DEPOSITS}

Terrace deposits -- Discontinuous deposits of weakly consolidated and variably sorted sand, silt, and gravel deposited on stream- and wave-cut surfaces. South of Olema fluvial cut- and fill-terrace deposits occur at three topographic levels (Grove and others, 1995). Deposits on the coastal terrace at Bolinas Mesa 40-60 m above sea level are less than a meter to more than $15 \mathrm{~m}$ thick, whereas southeast of Limantour Spit, where this terrace reaches sea level, these deposits are as much as $30 \mathrm{~m}$ thick and consist largely of subangular gravel of Monterey porcelanite and chert. Galloway (1977) correlates this coastal terrace with the lowest uplifted marine terrace(s) in the Santa Cruz Mountains, now dated at 81 to $105 \mathrm{ka}$ (late Pleistocene) (Dupré, 1991). West of Drakes Estero, a terrace surface at elevations of $76-90 \mathrm{~m}$ is veneered by poorly-indurated gravels and pebbly sands (Minard, 1971) and probably formed during the $320 \mathrm{ka}$ highstand (Lajoie, 1996). Scattered coastal terrace deposits east of Drakes Bay at elevations of about 98, 146, and $207 \mathrm{~m}$ were deposited on earlier Pleistocene wave-cut surfaces that subsequently have been dissected by erosion.

Older dune sands -- Weakly consolidated, laminated and locally cross-bedded, reddish-brown, well sorted, medium- to coarse-grained sand crops out discontinuously in the sea cliffs from Point Reyes to McClures Beach and in isolated exposures at Tomales Point. These beds, which locally are as thick as $30 \mathrm{~m}$, reach a maximum elevation of $60 \mathrm{~m}$ above McClures Beach, and are probably of Pleistocene age. These sands are believed to be eolian, as postulated by Minard (1971), rather than beach sands, as suggested by Cooper (1967) and followed by Galloway (1977).

Landslide deposits -- Only the larger slides in the vicinity of Double Point and at Bolinas are shown, where they consist mainly of intact to highly disrupted masses of Santa Cruz Mudstone. Deposits range in age from late Pleistocene (about 12,000 to 10,000 yr. B.P.; Rypins and others, 1989) to Holocene. For detailed mapping of landslide deposits see Wentworth and Frizzell, 1975.

Alluvium -- Poorly consolidated, poorly sorted clay, silt, sand, and gravel usually fill stream and valley floors. South of Point Reyes Station is as thick as $35 \mathrm{~m}$ (Wagner, 1977).

Dune sands -- Unconsolidated well-sorted, fine- to medium-grained sand. Nearly continuous belt of dunes occurs just east of the beach that extends for 11 miles north of Point Reyes. The active dunes at Dillon Beach north of Tomales Bay consist of trapped sediment moved inland by wind action (Cassa, 1990).

Beach sands -- Discontinuous accumulations of well- to moderately-sorted, fine- to coarse-grained loose sand locally are interspersed with pebble to boulder gravel.

\section{SOURCES OF DATA}

The most comprehensive publication on the geology of the Point Reyes Peninsula is by Galloway (1977), who summarized the previous geologic work. Other sources of geologic data that we used in our map compilation are show on sheet 1 . Our field work consisted of approximately three weeks of mapping in 1978 and 1979 that resulted in the recognition of three distinctive plutons within the granitic basement rocks and the recognition of two Neogene sedimentary sequences that are separated by a regional unconformity. We spent about seven additional field days in 1989 and 1996 mapping critical areas. 


\section{ACKNOWLEDGMENTS}

We are grateful to Don Lewis, former chief geologist of Chevron, for the release of well data and to Robert Fleisher also of Chevron for providing microfossil slides of Chevron Oil Company wells. We also are indebted to Krisin McDougall for identifying and interpreting microfossils, to Martin Link for measuring and interpreting the sedimentology of the Kehoe Beach section, and to the late Clyde Wahrhaftig for enthusiastically supporting this work and for collaborating with us on two field trips in 1990 and 1991 to the Points Reyes area. LeeRoy Brock, former Chief Park Ranger of Point Reyes National Seashore, greatly facilitated our field work in 1978 and 1979.

Carolyn Randolph, Heather Schoonover, and Carl Wentworth developed this digital version of the geologic map, and Carolyn Randolph prepared the booklet announcing the release of this database in Open Files. Partial funding was provided to Clark by USGS NEHRP award number 1434-HQ-96-GR-02741.

\section{$\underline{\text { REFERENCES }}$}

Blake, M.C., Jr., Bartow, J.A., Frizzell, V.A., Jr., Schlocker, J., Sorg, D., Wentworth, C.M., and Wright, R.H., 1974, Preliminary geologic map of Marin and San Francisco Counties and parts of Alameda, Contra Costa and Sonoma Counties, California: U.S. Geological Survey Miscellaneous Field Studies Map MF-574, scale 1:62,500.

Cassa, M.R., 1990, Point Reyes Beach, in Bilodeau, B.J., and Davis, S.O., eds., Geologic Guidebook to the Point Reyes area, northern California: American Association of Petroleum Geologists, Pacific Section Guidebook no. 66, p. 34-37.

Clark, J.C., Brabb, E.E., Greene, H.G., and Ross, D.C., 1984, Geology of Point Reyes Peninsula and implications for San Gregorio fault history, in Crouch, J.K., and Bachman, S.B., eds., Tectonics and sedimentation along the California margin: Society of Economic Paleontologists and Mineralogists, Pacific Section, Los Angeles, Calif., p. 67-86.

Clark, J.C., Wahrhaftig, Clyde, and Brabb, E.E., 1991, San Francisco to Point Reyes: Both sides of the San Andreas fault, in Sloan, Doris, and Wagner, D.L. eds., Geologic Excursions in Northern California: San Francisco to the Sierra Nevada: California Division of Mines and Geology Special Publication 109, p. 11-24.

Cooper, W.S., 1967, Coastal dunes of California: Geological Society of America Memoir 104, $131 \mathrm{p}$.

Curtis, G.H., Evernden, J.F., and Lipson, J., 1958, Age determinations of some granitic rocks in California by the potassium-argon method: California Division of Mines Special Report $54,16 \mathrm{p}$.

Dalrymple, G.B., 1979, Critical tables for conversion of K-Ar ages from old to new constants: Geology, v. 7, p. 558-560. 
Evernden, J.F., and Kistler, R.W., 1970, Chronology of emplacement of Mesozoic batholithic complexes in California and western Nevada: U.S. Geological Survey Professional Paper $623,42 \mathrm{p}$.

Galloway, A.J., 1977, Geology of the Point Reyes Peninsula, Marin County, California: California Division of Mines and Geology Bulletin 202, 72 p., map scale 1:48,000.

Grove, Karen, Colson, Kevin, Binkin, Marianne, Dull, Robert, and Garrison, Carolyn, 1995, Stratigraphy and structure of the late Pleistocene Olema Creek Formation, San Andreas fault zone north of San Francisco, California, in Sanginés, E.M., Andersen, D.W., and Buising, A.V., eds., Recent Geologic Studies in the San Francisco Bay Area: Society of Economic Paleontologists and Mineralogists, Pacific Section, v. 76, p. 55-75.

Lajoie, K.R. 1996, Inverness and Point Reyes anticlines, and Point Reyes syncline, in Jayko, A.S., and Lewis, S.D., compilers, Toward assessing the seismic risk associated with blind thrusts, San Francisco Bay Region, California: U.S. Geological Survey Open-file Report 96-267, p. 161-171.

Minard, C.R., Jr. 1971, Quaternary beaches and coasts between the Russian River and Drakes Bay, California: Berkeley, University of California Hydraulic Engineering Laboratory Technical Report no. HEL-2-35, 193 p.

Naeser, C.W., and Ross, D.C., 1976, Fission-track ages of sphene and apatite of granitic rocks of the Salinian block, Coast Ranges, California: U.S. Geological Survey Journal of Research, v. 4 , no. 4, p. 415-420.

Repenning, C.A., and Tedford, R.H., 1977, Otarioid seals of the Neogene: U.S. Geological Survey Professional Paper 992, 93 p.

Ross, D.C., 1977, Pre-intrusive metasedimentary rocks of the Salinian block, California--a tectonic dilemma, in Steward, J.H., Stevens, C.H., and Fritsche, A.E., eds., Paleozoic Paleogeography of the western United States: Society of Economic Paleontologists and Mineralogists, Pacific Section, Pacific Coast Paleogeography Symposium 1, p. 371-380.

1978, The Salinian block--A Mesozoic granitic orphan in the California Coast Ranges, in Howell, D.G., and McDougall, K.A., eds., Mesozoic paleogeography of the western United States: Society of Economic Paleontologists and Mineralogists, Pacific Section, Pacific Coast Paleogeography Symposium 2, p. 509-522.

1984, Possible correlations of basement rocks across the San Andreas, San Gregorio-Hosgri, and Rinconada-Reliz-King City faults, California: U.S. Geological Survey Professional Paper 1317, 37 p.

Rypins, Steven, Reneau, S.L., Byrne, Roger, and Montgomery, D.R., 1989, Palynologic and geomorphic evidence for environmental change during the Pleistocene-Holocene transition at Point Reyes Peninsula, central coastal California: Quaternary Research 32, p. 72-87.

Wagner, D.L., 1977, Geology for planning in western Marin County, California: California Division of Mines and Geology Open-file Report 77-15, 40 p., map scale 1:12,000. 
Wagner, D.L., and Bortugno, E.J., compilers, 1982, Geologic map of the Santa Rosa Quadrangle: California Division of Mines and Geology, Regional Geologic Map Series, Map no. 2A (Geology), scale 1:250,000.

Wahrhaftig, Clyde, and Wakabayashi, John, 1989, Tectonostratigraphic terranes, in Wahrhaftig, Clyde, and Sloan, Doris, eds., Geology of San Francisco and vicinity: American Geophysical Union, Washington, D.C., 28th International Geological Congress Field Trip Guidebook T105, p. 6-8.

Wentworth, C.M., and Frizzell, V.A., 1975, Reconnaissance landslide map of parts of Marin and Sonoma Counties, California: U.S. Geological Survey Open-file map 75-281, 12 sheets, scale 1:24,000. 